\title{
EXPLAINING THE LOSS OF COMMUNITY: COMPETING LOGICS AND INSTITUTIONAL CHANGE IN THE US BANKING INDUSTRY
}

\author{
Christopher Marquis, Zhi Huang and Juan Almandoz
}

\begin{abstract}
This chapter examines the transition in the US banking industry from a community to a national logic, developing a general model to explain how and when shifts in institutional logics occur. Based on qualitative historical evidence and discrete-time event history analysis predicting the introduction of legislation favoring the national logic, this chapter proposes that dramatic exogenous events such as the Great Depression or more gradual processes such as modernization favored the industry's transition to the national logic, but that such exogenous events had a greater influence in areas where strategic actors could capitalize on them. The qualitative evidence presented here suggests that struggles involving organizational identity and "legitimacy politics" played an important role in the shift in logics. Our theorizing focuses on how, when the environment changes in an incremental fashion, actors are primed with new
\end{abstract}

Communities and Organizations

Research in the Sociology of Organizations, Volume 33, 177-213

Copyright (C) 2011 by Emerald Group Publishing Limited

All rights of reproduction in any form reserved

ISSN: 0733-558X/doi:10.1108/S0733-558X(2011)0000033009 
possibilities, which may shift their collective identities, but when environmental changes are discontinuous, they provide actors strategic opportunities to alter the balance of logics in the environment.

Institutional logics provide broad sets of beliefs and norms that shape behavior, identities, practices and organizational forms in a given setting (see e.g., Thornton, Ocasio, \& Lounsbury, forthcoming). Those identities and organizational forms can in turn become "carriers of institutional logics" (Thornton \& Ocasio, 2008) that help perpetuate those logics. Although single institutional logics may be dominant and stable in some settings, they are always subject to reconfiguration. Research has documented how they can significantly change - especially over an extended period of time. Shifts in institutional logics can fundamentally reshape how organizations make decisions and operate (Lounsbury, 2002, 2007; Rao, Monin, \& Durand, 2003); for example, the transition from the community to the national logic in the US banking industry resulted in banks competing on scale and geographical coverage and made it critical for banks to develop capabilities and structures to manage geographically spread branches (Marquis \& Huang, 2009, 2010). Research has shown the impact of such transitions in settings as varied as French cuisine (Rao et al., 2003), publishing (Thornton \& Ocasio, 1999), healthcare (Scott, Ruef, Mendel, \& Caronna, 2000) and mutual funds (Lounsbury, 2007). Thus, understanding shifts in the dominant logic of a field is of great interest to organizational researchers.

Early studies of logic transitions, emphasizing the stability of institutional logics, adopted an exogenous view of transitions in institutional logics; that is, old logics are torn down and new logics are built up as a result of dramatic events external to a field, such as political or legal changes that mark transitions to new eras with different cultural, social, and economic logics (Davis, Diekmann, \& Tinsley, 1994; Davis \& Thompson, 1994; Mizruchi, Stearns, \& Marquis, 2006; Useem, 1993; Zajac \& Westphal, 2004). Recent studies have begun adopting an endogenous view of transition in logics, viewing environments as more fragmented and contested than previously thought. In this view, actors' competition over logics drives transitions in logics (Friedland \& Alford, 1991; Marquis \& Lounsbury, 2007; Rao et al., 2003). In this chapter, we focus on how these two views on logic shifts, each examined in isolation, are inherently incomplete. The exogenous view, while underscoring the impact of dramatic events as shocks to existing systems, may overemphasize their impact, potentially 
underestimating the role of logic-based competition and so fail to explain why there is variation in the impact of such shocks in different regions. By contrast, the endogenous view has yet to adequately explain how transitions in logics initially begin, when incumbents still enjoy absolute dominance over challengers, and how those transitions accelerate at specific points of time.

In this chapter, we track the transition in the U.S. banking industry's institutional logic from a community to a national logic by taking into account both endogenous processes of competition resulting from actors actively defending logics that provide them with identities and benefits, and exogenous changes that shape opportunities for actors to gain dominance in competition for logics. In essence, the model presented is interactive. We argue that exogenous events mainly represent forks in the road. Which institutional path a field takes is frequently a result of competition between actors espousing different institutional logics when they respond to opportunities created by the exogenous events. We suggest that the interaction of exogenous and endogenous forces is likely to lead to an extended period of debate and contestation over the appropriate way to organize field activities, rather than to sudden shifts in logics, as previous studies often depicted. In this model, in contrast to traditional work on institutional logics, exogenous forces have an impact mainly as strategic opportunities to radically alter the balance of logics. We argue that there is no shortage of exogenous forces in play, and identifying which are responsible for occasioning transitions requires consideration of the extant actors in the institutional field. The theory proposed here is that when the external environment is changing in an incremental fashion, actors are primed with new possibilities, which may shift their collective identities (Thornton \& Ocasio, 2008), and thus they affect the degree to which actors identify with previously embraced logics; but when environmental changes are discontinuous, they provide strategic opportunities for existing powerful actors to alter the balance of logics in the environment.

Historical research on the US banking industry has documented sustained debate and competition between two distinct organizing logics: a communityoriented logic focused on the advantages of locally owned and operated banks, and a nationally oriented logic focused on the efficiencies to be realized from geographic diversification of banking assets (Marquis \& Lounsbury, 2007). This tension reflects a deeper division in US history and society that dates to the founding of the United States and debates between Jefferson and Hamilton over the respective merits of centralized and decentralized economic and political structures. In light of prior work that 
has concluded that organizational forms reflect the "master principles of society" (Haveman \& Rao, 1997, p. 1614), the case of US banking is theoretically interesting because it illustrates the two deeply rooted, yet competing master principles of social organization as well as conflict between the different organizational forms that embody those logics. The main argument and the eventual finding of this chapter is that the banking industry's shift from a community to a national logic was assisted by modernization and by a dramatic historical event, the Great Depression, but their effects were contingent on the presence of strategic actors who identified with and sought to capitalize on the national logic.

The degree to which an institutional logic is dominant can be gauged by whether it is codified in laws and regulations (e.g., Dobbin, 1994), which are often "endogenous" (Kraatz \& Block, 2008) and which in turn reinforce the taken for granted nature of the logics (Meyer \& Rowan, 1977). The community logic is reflected by restrictive laws that prohibit banks from establishing geographically dispersed branches so that banks tend to focus on serving local communities where they are located, whereas the national logic is reflected by liberal laws that allow banks to branch out geographically to gain benefits from the economy of scale and scope by standardizing practices across branches. We thus examine the passage of liberal branching laws in 50 US states over the twentieth century as the results of the two types of exogenous change, the presence of unit vs. branch banks, and their interaction effects. For reasons we discuss later, we specifically focus on the period up until 1978. The period 1896-1978 saw 41 instances of states relaxing geographic restrictions thus reflecting the nationally oriented logic.

Our theoretical understanding of this process is grounded in an exploratory study of meeting minutes from national, regional, and state banking associations (see appendix) and in hypotheses tested on an annual time-series dataset of changes in US state laws that extends from 1896-1978. Numerous theorists have argued that a challenge to deep understanding of institutional change is lack of fine-grained historical detail and extended time sequences (Barley \& Tolbert, 1997; Leblebici \& Shah, 2004). These authors recommend that organizational theory must conduct more historical research to remedy this issue. The transcribed minutes at those associations' meetings reflect the bankers' identification with two distinct organizational identities in conflict, divided along the lines of community and national logics; those minutes also reflect "legitimacy politics" (Stryker, 2000), contestation that led to the gradual domination of the national over the community logic, as reflected in specific legal changes. The shift from community to national logic was the 
result of modernizing economic and technical conditions which created new opportunities for banks to expand, and which incentivized a shift in bankers' identities. To assess the interactive effect of identities and external environments which led to tipping the balance in favor of a national logic, we conduct event history analyses of the passage of state laws in the 48 contiguous US states between 1896, approximately when the debate began, and 1978, the year that we suggest below marks the transition to the next phase.

Our primary theoretical contribution is to study the process of historical change in institutional logics, particularly as they are represented in actor identities. More specifically, given the logic examined (in the particular context of the banking industry), this chapter contributes to the understanding of the "loss of community" in society, a theme that has interested many early sociologists (Tönnies, 1887; Weber, 1978[1968]), and a few recent economists (e.g., Marglin, 2008). We suggest that because institutional logics are intimately related to actors' identities (Rao et al., 2003), they are less passive than typically conceptualized and actors engage in strategic action to defend and promote their worldviews (Marquis \& Lounsbury, 2007). Regarding the external changes that are so essential to institutional explanations, we argue that these have the effects they do as a result of opening opportunities for these actors; gradual changes, such as the processes of modernization, prime actors with new possibilities and thus lead to a shift in identities, and discontinuous changes such as the Depression allow one group of actors to take precedence over another.

We conclude that although historical periods might have relatively punctuated boundaries, shifts between them are more a culmination of prior events than simply a result of a few dramatic exogenous shocks. Our exploratory historical investigations suggest that one reason for the extensive back-and-forth between the opposing logics at the state level, and for the relatively long time it took for one logic to gain dominance, was the presence of countervailing environmental forces, and actors that supported both sides. Thus, the theoretical perspective offered by this chapter also suggests that transitions in logics are not necessarily irreversible. Other exogenous shocks such as the financial crisis of 2008 could reconfigure the balance of logics in favor of the community logic, such that interested actors could capitalize on those opportunities. Given that the community logic in the US banking industry has persisted and that it even still thrives in some settings (Almandoz, 2010; Marquis \& Lounsbury, 2007), we believe that a similar phenomenon as the one described here, but in reverse, could happen again. 


\section{COMPETING LOGICS AND THE STRUCTURE OF THE US BANKING INDUSTRY}

There have been two alternative logics to organize banking operations in the U.S. the community logic and the national logic. The community logic emphasizes that banks focus on serving local communities and to do so often requires banks to deeply embed themselves in local communities by developing close relationships to local patrons. As a result, banks following this logic often do not branch out of the local communities they serve. They are single-unit banks. The national logic emphasizes that banks are able to gain benefits from scale and scope through geographical diversification. Banks following this logic often establish branches in different locations and standardize operation across branches instead of customizing their services to local communities. Community and national logics are therefore "incarnated" in particular organizational forms (Greenwood \& Suddaby, 2006; Haveman \& Rao, 1997).

The distinction between these two alternative logics can be traced to the core philosophical positions of the two major political parties present at the founding of the United States. The Republicans, led by Thomas Jefferson, preferred decentralized political and economic systems with community-oriented control of banks; the major opposing party, the Federalists, led by Alexander Hamilton, preferred centralized political and economic systems with large, multiplebranch, national banks. Friedland and Alford (1991, p. 246) note that "the persistent tendency for Americans to construct decentralized state structures, to separate governmental power, to prevent the emergence of national banks ... derives in part from a culturally contingent concept of power, embedded in a notion of liberty derived from the original settlers' experience of a highly intrusive English state."

The conflict over community versus national logics in social life in general, and in the banking industry in particular, has been repeatedly described throughout the US history. Tocqueville ([1835]2000), for example, during his extended trip to the United States in 1831 and 1832, maintained that the vibrant community life in the United States served as an antidote to centralized state and economic powers. The principle of community sovereignty was shown by Dobbin (1994) to be essential in understanding US economic and political behavior in the nineteenth century. Friedland and Alford's (1991) observation that conflict has been a particularly salient feature of US banking is reflected in Andrew Jackson's 1830s veto of the charter of the Second Bank of the United States, an early branch bank. 
Stated Jackson: "It is easy to conceive that great evils to our country and its institutions might flow from such a concentration of power of a few men irresponsible to the people" (quoted in Roe, 1994, p. 58). Resistance to the nationally oriented logic, albeit marginalized, persists to this day in the US banking industry (Marquis \& Lounsbury, 2007), as evidenced by the rhetoric against Wall Street banks following the 2008 crisis (see for instance moveyourmoneyproject.org, the website of a campaign encouraging people to move their capital away from Wall Street).

Such a conflict played out in legislative change when actors espousing either logic sought to influence state regulations to advocate their beliefs as well as defend their interests. The industry hosted opposing groups of actors with dramatically different identities and hence visions of how to organize US economic life. As Friedland and Alford (1991) theorize, these visions were central and durable features of organizational identities. The particular legislative battles revolved around whether banks would be allowed to establish geographically dispersed branches or not, echoing the distinction between the two logics of organizing bank operations.

Fig. 1 illustrates for the entire twentieth century the extent to which banks were legally prohibited from establishing branch locations. As shown, during this approximately 100-year period, the US banking industry underwent a fundamental shift in organizing logic as manifested in the erosion of the

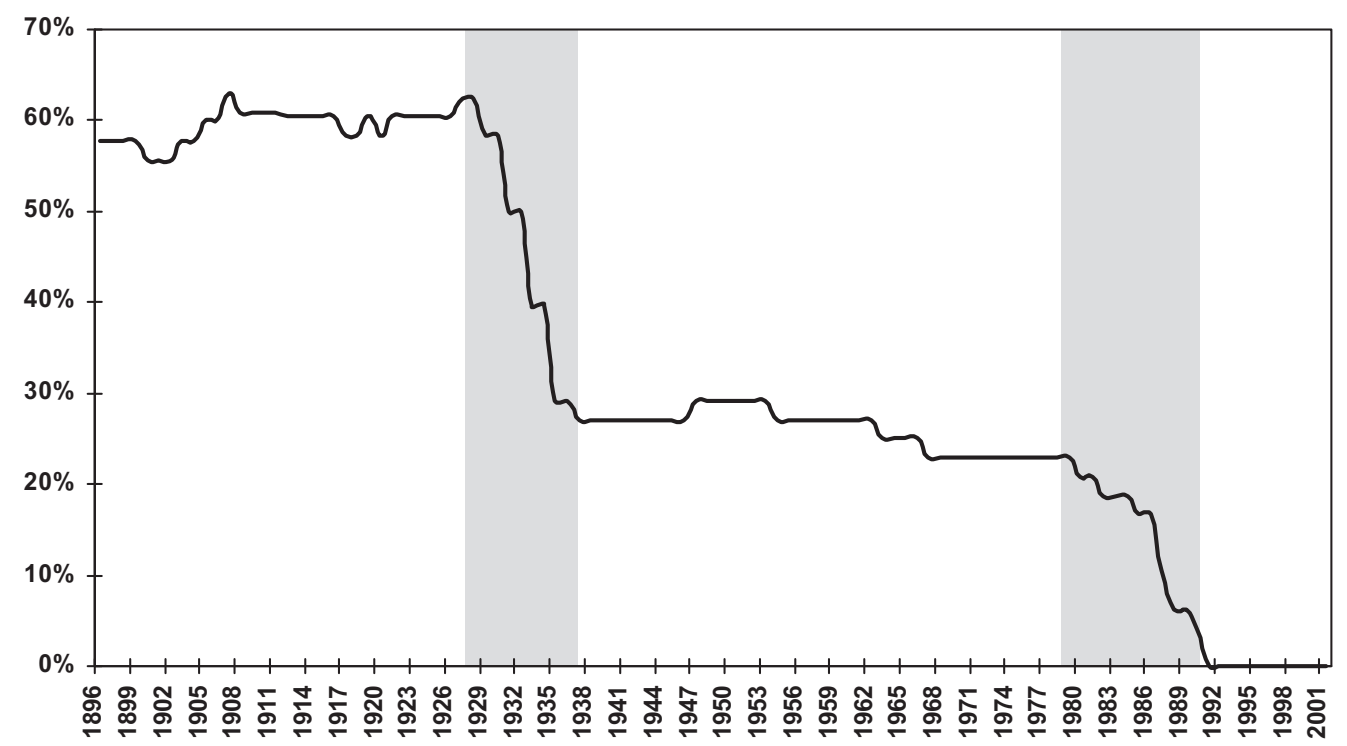

Fig. 1. Percentage of US States Prohibiting Bank Branching, 1896-2001. 
community logic and conversely the rise of the national logic. At the turn of the twentieth century, about 60 percent of US states had laws that explicitly prohibited branching. Across more than 12,000 commercial banking firms in 1900, only 119 had branches. But by the early 1990s, with no US states still prohibiting branching, the approximately 12,000 separate banking organizations extant at that point had more than 80,000 bank branches.

What is not as apparent from looking at this figure, with its three apparently stable eras and two sharp periods of transition, is that during this entire period, there were many offsetting changes. In 1968, for example, Florida liberalized and Montana restricted local banking laws. Although the graph shows a general erosion of the community-oriented logic, on a yearto-year basis, a battle between the competing logics was played out at the US state level within industry trade associations and, ultimately, in the offices of legislators and state legislatures by organizational actors working to align state regulations with their respective logics. This process of continual opposition by two deeply entrenched banking logics and identities across the US states is congruent with similar struggles in other settings. Research evidence suggests that legislative changes assumed to have manifested and precipitated shifts in logics (see, e.g., Davis et al., 1994; Fligstein, 1990) were not easily settled affairs. The figure further shows, also consistent with traditional work on institutional logics, that the transition between periods appears to be discontinuous and to correspond to periods of major federal regulatory shifts, be they responses to the Great Depression or the deregulatory fervor that began in the late 1970s. Thus, we explore below how shifts in logics as manifested in legislative change occur as a result of opposing actors competing to advocate different logics in the opportunity structure shaped by exogenous changes.

\section{Competing Logics, Organizational Identities, and Institutional Change}

Logics are more than passive belief systems, as often conceptualized. "[L]ogics constitute the identities of actors" (Rao et al., 2003, p. 796); they are critical components of the identity of organizations, of "that which is central, distinctive, and enduring" about organizations (Albert \& Whetten, 1985), and as such logics are often purposefully adopted, sometimes passionately embraced, by organizations and individuals. For example, classic cuisine and Novelle cuisine follow different logics that define different role identities for chefs consciously and passionately embraced by them (Rao et al., 2003). 
In the case of the US banking industry, according to the community logic, banks are and should be "owned in the community and operated for the profit of the stockholders and for the benefit and development of the community in which it exists ... The unit bank is the heart of the community and furnishes the circulation of the life blood of business" (National Association of Supervisors of State Banks Convention, 1934, p. 90). By contrast, according to the national logic, banks are and should be expansive systems with standardized branch operation across different geographical locations and thus represent modernization and economic efficiency. Defending the national logic incarnated in multibranch banks, William B. Ridgely, comptroller of the currency, stated at meetings of the American Bankers Association: "I believe in branch banking. Theoretically, it is the best system, as it is more economical, more efficient, will serve its customers better, and the organization can be such as to secure in most respects better management" (American Bankers Association, 1902, p. 72). Thus, the identities of banks organized according to the community and the national logic are deeply felt and in sharp opposition to each other.

When actors identify themselves with an institutional logic, they claim the identity provided by the logic. Internalized identity entails "valuation orders" (Thornton \& Ocasio, 1999, p. 805) that can generate principled adherence to established logics. Logics provide desirable images that can be used by strategic actors to craft organizational identities and derive stakeholder support (Scott \& Lane, 2000). In the context of community banking, it becomes evident that logics provided desired images, which helped banks define what was "special, unique, or distinctive about [their] organizations to relevant audiences" as well as what their "core values" and "central beliefs" were (Scott \& Lane, 2000). To defend their world view, unit banks framed the debate as one of community banking versus consolidated capital. The community-oriented identity and logic were firmly based in the advantages of decentralized economic systems and the sacrosanct connection between depositors and bank directors that would be broken by branching giving rise to an industry dominated by large, impersonal institutions (Chapman \& Westerfield, 1942; Fischer, 1968). This was the thrust of remarks by Charles G. Dawes, president of Chicago's Central Trust Company of Illinois, who insisted: "It is folly to maintain that an agent of a branch bank, acting at a distance under delegated authority, can exercise the same discretion and have the same latitude in the making of loans in which the personal equation is an element as does the local bank acquainted with local conditions and authorized to cope with a local situation" (American Bankers Association, 1902, p. 117). 
Hence, although the unit banks controlled only a small percentage of overall industry assets, the community identity of these firms was quite resonant with and thus often gained the support of the public and politicians. The strength of such sentiments is reflected in a mid-1930s survey that found 90 percent of Nebraska unit bankers opposing branching (Kuhn, 1968). A 1924 Illinois referendum rejecting branching by a large majority (White, 1984), with opposition greatest in areas with a significant unit bank presence, is evidence of strategic action on behalf of these banks. Newspaper accounts and other historical records of the time that documented unit bankers' severe public critiques of branching legislation suggest that the public was influenced by the unit banks' strategic rhetoric. Finally, formal resolutions issued in 1923 declaring the Kansas, Missouri, and Pennsylvania bankers' trade associations to be opposed to branch banking are evidence that unit bankers were able to translate their logic and power into political positions.

Although unit bankers defined their identity in terms of desirable community images and negatively framed their opponents as consolidated financial power, by contrast, large, urban, and branch banks expressed their own identity in terms of a nationally oriented logic drawing on images of modernization, economic efficiency, and safety, which were assumed to be greater as banks grew in size and geographic scope. In strategically defending their identity, multi-unit banks argued that modernization and economic efficiency was on their side and that banks with branches, because they spread credit risk across multiple geographies, were safer (Collis, 1926; Fischer, 1968). A. P. Giannini of the Bank of Italy (later Bank of America), who spent months at a time touring the country in his Cadillac to rally support for the expansion of branching, was emblematic of the strategic actors who devoted considerable time and energy to mobilizing support for branch banking (James \& James, 1954).

Such identity-based competition over logics was directed to change state regulation over bank branching. Our historical investigation suggests that organized trade associations, frequently seen by researchers as mobilizing structures (Ingram \& Rao, 2004), linked competing groups with divergent identities to changes in legislation. A unique feature of banking is that state affiliations were important to both types of banks (i.e., unit and branching banks), which led both groups to belong to the same state banking associations. This was the case both because banks were incorporated in and thus naturally identified themselves with their home states and because these associations provided necessary services (e.g., pooled burglary protection and insurance). ${ }^{1}$ These associations were essential to the advancement of 
bankers' world views by providing an infrastructure for influencing opinions and a connection to lawmakers. As such, in the annual budgets of almost all these associations, the largest line item was associated with the "legislative committee," the group that constituted the liaison with state governments and activists. These associations engaged in a wide variety of activities to influence opinions. ${ }^{2}$ For example, it was recorded in an annual proceedings of the American Bankers Association (1912) that one such committee "has devoted much time and attention to the various measures by personal attendance of a number of its members at Washington on different occasions, by mail and by telegraph, and has enlisted the active support and co-operation of Clearing House Associations, States Bankers Associations and other organizations and individuals along lines of procedure mapped out by the Committee" (p. 237).

Due to the instrumental role of state bank associations, opposing constituencies within the banking industry worked within these existing associations to have them adopt and endorse positions consistent with their respective identities and logics. Trade associations were often forced to take firm positions on issues instead of straddling so that they represented just one position when influencing legislation. Recall, for example, that in 1923 a number of associations declared themselves opposed to branching. Thus, through debating and then voting within the associations, banks supporting opposing logics labored to influence the position that bank associations took. Many years' proceedings record members' votes on the respective sides of debates aimed at focusing the associations' position. Although banks' financial size might be presumed to exert more influence than other factors on voting results, examinations of meeting minutes and other historical work (Calomiris, 1993) suggest that their larger numbers lent single-unit banks considerable leverage. The connection between voting and advocacy is in evidence in New Jersey in 1915; the state bank association "determined to use every endeavor to prevent the extension of branch banking" (New Jersey Bankers Association, 1915, p. 91) after voting was taken and the majority of the members opposed the expansion of branching laws. There was typically substantial debate over these issues and often a relatively small margin tipped the balance, as was the case in New York in 1934 when the association's advocacy was determined by vote of 198 opposed to 135 in favor of a branch banking measure.

To sum up, the preceding theorizing based on extensive historical evidence suggests that banks supporting the opposing logics of organizing bank operations competed to influence state legislators to pass more restrictive or more liberal branching laws. And state bank association 
endorsement constituted a key path to legislative change to the extent that state bank associations represented banks in dealing with state legislators. As such, competition over logics among banks first played out in state bank associations when banks debated and voted to determine the position taken by state bank associations when influencing state legislation. Consistent with Greenwood and Suddaby's (2006) argument that organizational form is a key representation of institutional logics, and Haveman and Rao's (1997) conclusion (p. 1645) that organizational forms are "incarnations of logics," we hypothesize that the relative presence of carriers of various logics led to policy changes consistent with the underlying institutional logics of those banks.

Hypothesis 1. The greater the relative presence in a state of actors with a nationally oriented banking logic (i.e., multi-unit banks), the more likely that the state will pass liberal branching legislation.

\section{Exogenous Changes and Opportunities for Institutional Transitions}

Exogenous changes no doubt impinge on the existing institutional system. For example, research on institutional change traditionally considers external changes (typically either legal or economic) as shocks to the existing institutional system which consequently create shifts in institutional logics (e.g., Haveman \& Rao, 1997). Similarly, in the context of US banking, Fig. 1 shows that coinciding with the Great Depression there is a drastic drop in the percentage of US states with restrictive bank branching laws, seeming to suggest the punctuating effect of exogenous shocks. However, we suggest that the effect of exogenous changes on institutional logics may be more subtle than just automatically creating "shifts" in logics. To understand such subtleties requires insights into how actors support different institutional logics and how different identities react to exogenous changes in ways that shape competition over logics.

We suggest that actors' reactions may vary with whether exogenous changes are discontinuous or gradual. Discontinuous changes may suddenly create enormous uncertainty which strategic actors can leverage as an opportunity to alter their balance of power with respect to their opponents. Gradual changes unfold over time so their influence may progressively penetrate social actors leading them to spontaneously change their beliefs and identity as adaptive responses (Gioia, Schultz, \& Corley, 2000; Rao, Monin, \& Durand, 2005). Hence, strategic actors' reactions to gradual 
exogenous changes may be less contentious and conflict-ridden than those due to discontinuous exogenous changes, even if perhaps they lead to dramatic long-term effects. Such consideration suggests that there is not only a primary effect of exogenous changes on institutional shifts but also a secondary effect contingent on strategic actors' reactions. In the context of the US banking industry, we specifically examine the impact of the Great Depression as a discontinuous exogenous change and of modernization as having a gradual effect on the passage of liberal branching laws in US states. Given the difficulty in capturing the subtlety in actors' reactions to exogenous changes, we extensively draw on historical materials for illustration and to supplement our quantitative analysis.

\section{The Great Depression and the Passage of Liberal Bank Branching Laws}

Discontinuous changes typically lead to an era of ferment characterized by uncertainty, where there is competition between organizing logics and opportunities for new solutions (Tushman \& Rosenkopf, 1992). Barley and Tolbert (1997, p. 102) theorized that "changes in technology, cross-cultural contacts, economic downturns and similar events increase the odds that actors can (or must) modify an institution." Thus, periods of dramatic changes provide opportunities for actors to shape the broader institutional system according to their own logics and interests. Although much prior work on discontinuous change has focused on the evolution of technology, there are reasons to believe that these arguments apply to political changes as well. Greenwood and Hinings (1996, p. 1043), for example, suggest a model whereby "performance problems and crises act to trigger political dissensus over existing arrangements and permit groups less committed to prevailing practices to more legitimately raise and promote alternative perspectives." Thus, in some cases, new opportunities arise in the political system. Opportunities on which strategic actors can capitalize (Tarrow, 1998). Barley and Tolbert (1997, p. 102) stress the importance of these openings since under usual circumstances, "change is likely to be constrained by the intransigence of others who, in lieu disturbance in the status quo, are likely to resist reopening previously negotiated arrangements."

This seems to be the case in the US banking industry. The historical meeting minutes suggest that the perceptions of the public and legislators were dramatically affected by the Great Depression, but that how they interpreted this drastic event was not straightforward. Not surprisingly, divergent interpretations emerged from actors with competing logics and identities (Lok, 2010). The legislation spawned by the Depression followed 
considerable debate, particularly over questions of how to interpret the banking troubles in light of the question of bank expansion.

Nationally oriented bankers emphasized the disproportionate number of unit banks that had failed. To counterattack, unit bankers, pointing to the considerable number of branch banks that had failed as well, suggested that the underlying problem had to do with bank chartering procedures instead of any particular organizational form. Further, unit bankers argued that failures of unit banks were limited to a few states, which suggested that there were underlying conditions of the state that led to the problems, not unit banking per se. There were legislative trade-offs. Even as communityoriented bankers succeeded in blocking an early provision in the GlassSteagall Act that would have permitted national branching, nationally oriented actors were "taking advantage of the Depression hysteria to conclude in their favor the battle that has been going on for a number of years ... It is a fight," the record continues

\begin{abstract}
between the unit banker ... and the proponents ... of branch banking ... Those who are using the propaganda that the unit country bank has been a failure are putting forward the remedy of "Safety in Bigness"; that is, the safety of the foreign system of nation-wide branch banking. Their argument is based upon an absolutely false position. They say that the unit country bank has been a failure, and that the large number of failures among the smaller banks... makes it necessary to change." (American Bankers Association, 1933, pp. 14-16)
\end{abstract}

Other documents at the time and later suggest that, although in fact small bank failures were isolated, the accepted wisdom came to be that small bank failures had contributed to the Depression (e.g., Calomiris, 1993), particularly through the publicity generated by agents of the national logic, who sought the enactment of branch banking laws. ${ }^{3}$

Thus, historical evidence suggests that the Great Depression influenced the passage of liberal bank branching laws in US states in two ways. First, the massive economic crash and consequent federal legislative changes likely affected all states. Second, the Great Depression's influence at least partly depended on debate between, and propaganda of actors espousing, different logics about the most adequate causal interpretation of the Great Depression. Although the general belief was that unit banks contributed to the Great Depression as noted earlier, such a belief might be stronger where proportionally there were more branching banks compared to unit banks. In those states, branching banks were likely to have more weight in the interpretation of the cause of the Great Depression, leading to more liberal branching laws. We thus suggest both the direct and the interactive effect of 
the Great Depression on the passage of liberal bank branching laws in US states.

Hypothesis 2a. The Great Depression led states to be more likely to pass liberal bank branching legislation.

Hypothesis 2b. The effect of the Great Depression was heightened in states with more actors with a nationally oriented banking logic (i.e., multi-unit banks).

\section{Modernization and the Passage of Liberal Bank Branching Laws}

Modernization was an important change that had deep impact on almost every aspect of the US society. For example, its impact on organizations is recounted by Haveman and Rao's (1997) study of how modernization gave rise to a new form of mutual savings organizations. Of particular importance for the US banking industry are two modernization processes, i.e., urbanization and the development of transportation technology (Marquis \& Huang, 2009, 2010). Through urbanization, cities grew bigger and customers became increasingly sophisticated and demanding, which created new challenges for banks. One particular challenge related to branching was how banks could maintain their business relationships with their customers when these customers increasingly moved to suburban areas with the growth of cities. Consider the history of Michigan-based Comerica Bank (Comerica Bank, 1999, p. 31): "When most Detroiters still lived around the downtown area, one office served the bank well. As the population moved to the edges of the core city and beyond, banks, like other retailers, had to follow if they wished to remain competitive in serving customers." To respond to this challenge, banks often need to establish branches close to their customers who lived in much bigger urban areas. Various histories of banking suggest that the growth of cities stimulated banks' establishment of branches (Collis, 1926; Fischer, 1968).

The development of transportation technology created new opportunities for banks to serve geographically dispersed customers through branching by overcoming constraints from doing so. Banks faced two particular constraints from branching out to dispersed geographical areas. First, banks that created outlying branches became dependent, owing to agency issues, on physical communication. Chapman and Westerfield's (1942) exposition of the management of bank branches describes a range of paper systems banks used to monitor branch activities, among them, duplicate records, daily reports, and documentation of personnel, financial 
statements, and other information on business conditions, all of which had to be transported between the branches and headquarters. Second, to effectively manage multibranch banks requires the close inspection of branches by headquarters personnel. Branch locations were monitored by traveling staffs of auditors similar to the "inspectors" or "road men" who administered geographically dispersed chain stores (Chandler, 1977). White (1984) notes a shift in branching activity during the 1920s as agency issues began to be addressed as a result of improvements in transportation that facilitated travel.

Haveman and Rao (1997) describe how modernization altered consumers' support of traditional forms of mutual savings organizations leading to traditional dying organizations being replaced by new organizations that embodied the new logic. The historical materials we consulted, however, suggest that the process was not so much one of organizational selection and replacement as of changes in the external environment priming shifts to new identities promoted by existing actors. As the country modernized in the twentieth century, some unit banks, as they gained a new understanding of what was possible, shifted their views and identities accordingly (Gioia et al., 2000). Similar to the identity migration processes shown by Rao, Davis, and Ward (2000), branch banking became more accepted and desirable as states become more urbanized, and transportation developments allowed suburbanization.

The link between changing environments and the need for compensating adjustments in the regulation of banking was evident in an address by the president of National Capital Bank of Washington at a meeting of the American Institute of Banking.

Five or six years ago it became evident that the power of the national banking system was not increasing in proportion to the development of industry or commerce ... [B]ranch banking is not a problem in the smaller cities of the country, but it is a very acute problem in the larger cities, where the population is shifting rapidly and new business areas are springing up. (American Institute of Banking (AIB) 1927, pp. 61-68)

The influence of both urbanization and transportation is in evidence in the shift in American Bankers Association discourse on branch banking between 1916 and 1930. Tied explicitly to modernization, the shift occurred during debate over the course of three meetings. In 1916, ABA's Federal Legislation Committee, wanting to understand association members' positions on branching as a way to resolve ambiguity about the relative strength of the opposing logics, brought the topic to the floor of a meeting, prompting extensive debate (nine pages of typed dialog) and resulting in a resolution 
stating the trade association's opposition to branching. A second formal resolution, passed in 1923, reiterated this position. In 1930, however, the ABA issued the following revised resolution, tying changes in branching policy directly to modernization pressures.

Modern transportation and other economic changes, both in large centers and county districts, make necessary some readjustment of banking facilities. In view of these facts this Association, while reaffirming its belief in the unit bank, recognizes that a modification of its former resolutions condemning branch banking in any form is advisable. The Association believes in the economic desirability of community-wide branch banking in metropolitan areas and county-wide branch banking in rural districts.

(American Bankers Association, 1930, pp. 134-135)

One might anticipate that, as urbanization increased and the transportation infrastructure improved, the potential of branching would be recognized by growing numbers of banks and generate greater support for establishing branches where they were not yet permitted. Prior work in economic history has suggested such a relationship. Abrams and Settle's (1993) study of changes in branching laws during the Great Depression, for example, links increasing urbanization to the relaxation of branching laws, and Calomiris (1993) describes how during the 1930s banks in "limited banking" states established city branch networks that increased their power, and then lobbied for full state-wide branching. This prior work on the growth of branching suggests that the logic of organizing among banks shifted as states urbanized and connected to suburban areas, resulting in bank associations lobbying legislatures to liberalize banking regulations. An interaction effect between the strength of the respective logics in terms of the composition of banks and modernization is likely inasmuch as the idea of branching, even as it was gaining acceptance in banks, was likely also gaining acceptance in broader society. Lobbying from multibranch banks over state legislatures was likely to be more effective leading to more liberal branching legislation in states that were experiencing modernizing trends where multibranch banks were proportionally in greater representation.

Hypothesis 3a. States that are more highly urbanized are more likely to pass liberal branching legislation.

Hypothesis 3b. The effect of urbanization is heightened in the presence of relatively greater numbers of actors with a national-oriented banking logic (i.e., multi-unit banks).

Hypothesis 4a. States with a more developed nonurban transportation infrastructure are more likely to pass liberal branching legislation. 
Hypothesis 4b. The effect of the development of transportation is heightened in the presence of relatively greater numbers of actors with a nationally oriented banking logic (i.e., multi-unit banks).

\section{METHODS AND ANALYSES}

\section{Sample and Dependent Variables}

To test these hypotheses, we examine annual state-level banking laws for all contiguous US states from 1896 through 1978. As noted, there is substantial evidence that the branching debate began around the turn of the twentieth century and 1896 is the date when the federal government began systematic collection of state-level banking information. We terminate our analysis in 1978 mainly because legal changes enacted that year that permitted banks to engage in interstate banking would confound these analyses that treat each state as a separate institutional environment. Further, some of our predictions relate to modernization, and as time progresses, differences between sates in modernization becomes increasingly meaningless. The annual state-level data yields 3,941 state-year observations (48 observations for each year, except years that predate Oklahoma statehood in 1907 and New Mexico and Arizona statehood in 1912). We created for each of the 48 contiguous states in the sample from 1896 to 1978 annual state-level legal environment and regulatory histories. Lacking a pre-existing list of these for each state, we examined more than 15 secondary sources as well as, in many cases, actual state statutes. ${ }^{4}$ Regulations were divided into four categories from most liberal to most restrictive: full state-wide banking (i.e., no geographic restrictions on locations); full state-wide banking, but only by merger, (i.e., banks could expand only through acquisition, not by establishing branches); limited statewide banking (banks were permitted to establish branches within geographic restrictions); unit banking (banks were limited to a single location). ${ }^{5}$ There were 41 regulatory changes from more restrictive laws to more liberal laws between 1896 and 1978, representing our dependent variable.

\section{Independent Variables}

To assess the relative influence of actors espousing different institutional logics during institutional changes in a given state, we simply relied on the 
presence of two types of banks (i.e., multi-unit banks vs. unit banks) and adopted the simple measure of the percentage of multi-unit banks (or conversely unit banks). The data used to construct this measure was from the Federal Reserve's counts of banks and branches published annually from 1929 to 1992 as well as a number of historical compilations that extend back to the late nineteenth century. A number of years between 1896 and 1929 are linearly interpolated. ${ }^{6}$

To account for the effects of the Depression, we included an indicator variable for the years between 1929 and 1935. To assess modernizing forces in the environment represented by urbanization, we measured the total population that lived in urbanized areas (logged). Although some of the qualitative data presented earlier suggested that it was suburbanization processes, not urbanization per se, that might have contributed to growth, the fine-grained data on spatial distribution of the population needed to assess this is not available for the period studied. The data were obtained from the US Census Bureau at 10-year intervals beginning in 1890 and interpolated in between. As a measure of transportation infrastructure, we used roadway expansion beyond centralized population areas. This measure has the benefit that it also captures suburbanization processes. We obtained state data on nonurban highway mileage from the U.S. Department of Transportation's annually published Highway Statistics. To correct for size of a state, we divided these values by the total land area in square miles of the state. These data become available at the state level in 1923, so to analyze the entire historical period, we extrapolated the series back to 1896 using data on total highways. ${ }^{7}$ Given that the outlying highway system did not grow significantly until after 1923, this extrapolation should not bias the analyses, and results are consistent when the extrapolated data are excluded from the analysis. To address the degree to which banks in other states influence a focal state's actors and legislation, using the data sources described earlier, we include the total of unit banks that are in the focal state's census region.

\section{Control Variables}

Prior studies have found that strength of supportive organizations can affect policy decisions at state, local, and national levels (Cress \& Snow, 2000; Ingram \& Rao, 2004). For example, Ingram and Rao (2004) find the number of retail employees in a state, presumed to be allies of the chain store movement, to be negatively related to the state passing an antichain law. 
Large manufacturing firms desirous of a more convenient and stable banking system were a potentially important constituent in the branch banking debate (Calomiris, 1993). In states in which manufacturing was expanding, those firms likely pushed for laws that enabled the concomitant growth of banks through branching. The power of manufacturing was gauged by the percent of the population that worked in manufacturing calculated from data collected from Historical Statistics of the States of the United States (Dodd, 1993) and the Census Bureau. Farming and small town interests, on the other hand, hopeful that their local banks would continue to supply credit during economic downturns, opposed branching (Roe, 1994). Data used to measure the number of farms in a state (logged) were drawn from the US Agriculture Department's historical database on farms. Because this data exists only back to 1910 , values for the period before that were linearly extrapolated (using the "epolate" command in STATA). Further, to gauge the possibility that it is not multi-unit firms, but larger firms that would be desirous of changing the laws; we include a control for the average size of banks in a state, measured as total average deposits.

Prior research has also shown that lawmaker preferences can make it easier for a given group to influence the nature of legislation that is passed (Burstein \& Linton, 2002; Soule \& Olzak, 2004). For example, Democrats are usually presumed to be liberal and favor policies oriented toward overall social welfare (Burstein \& Linton, 2002; Huber, Ragin, \& Stephens, 1993), Republicans to be more conservative (Soule \& Olzak, 2004), and supportive of policies that favor corporate interests (Garrett, Wagner, \& Wheelock, 2003; Kroszner \& Strahan, 1999). Lawmaker effects were captured by determining (from ICPSR databases) whether a state's governor was Republican. We also include as control variables per capita income (measured using data from the Bureau of Economic Analysis and, prior to 1929, from Population Redistribution and Economic Growth, 1870-1950 (Lee, Miller, Brainerd, \& Easterlin, 1957)), and total state population (measured using data from the US Census Bureau). We also included a linear time trend variable and, to account for repeated events in the study, a variable for whether a state had previously implemented a similar law.

\section{Models}

Our use of discrete time event history analysis to analyze these panel data with a dichotomous dependent variable (Allison, 1995) is consistent with empirical strategies employed by others who have investigated similar processes (e.g., Schneiberg \& Bartley, 2001; Soule \& Olzak, 2004). As 
Yamaguchi (1991) and these authors have noted, discrete time models are appropriate for such data because the event of interest can occur only at regular, discrete time points (years) and state-level covariates are measured in yearly increments.

A few differences between our analyses and what has been done before also warrant mention. Although establishing within-group robust standard errors was appropriate given the shorter time span of Soule and Olzak's (2004) study, because of our longer time period we have more observations per group than groups (see the methodological appendix in Mizruchi \& Stearns, 2001 for a discussion). For our data, random effects, used in the reported logit models, are a better way to account for multiple observations per state. Also, our right censoring rule differs from those used in prior investigations. In studies that deal with the passage of one type of law, when the law is passed the state is censored. But in our study, states can make multiple changes and are not censored until they reach the extreme ends of the regulatory continuum (statewide and unit). The populations "at risk" for these analyses thus include all states in a given year that have not yet become statewide or unit banking states. Because of censored values, our analyses are conducted on a dataset of 2,779 state-year observations. Table 1 presents descriptive statistics and correlations.

\section{RESULTS}

Table 2 presents the models that test the foregoing hypotheses. Model 1 includes the control variables. Results obtained with some of the control variables are also of interest. Although not fully significant at the 0.05 level in all analyses, the existence of allies (Ingram \& Rao, 2004) appears to be an important factor in this context; the percentage manufacturing employment was a marginally significant influence on the liberalization of laws. Farmers also appear to have had a countervailing force on the liberalization of laws. Given that these actors also shared the underlying positions of the respective banks, these findings are further evidence that the division between community- and nationally oriented logics runs deep in the United States.

Model 2 tests Hypothesis 1. As might be expected, and consistent with Hypothesis 1 in model 2, the percentage of banks with branches is a significant predictor of a state's passing a more liberal branching law, suggesting that the prevalence of actors that support the nationally oriented logic influences the passage of laws. Model 3 tests Hypothesis 2a by including the dummy variable that captures the Great Depression. As would 


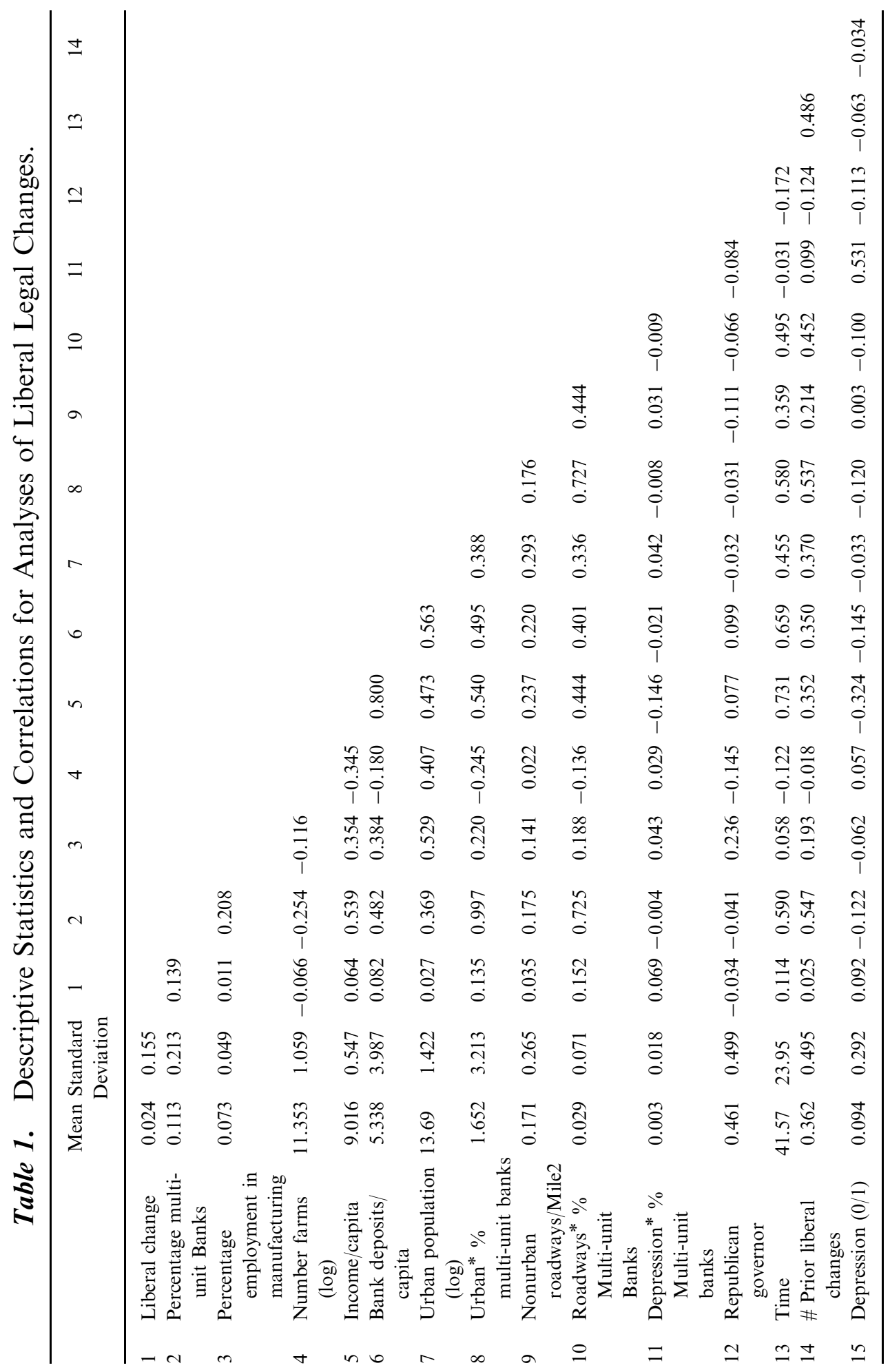




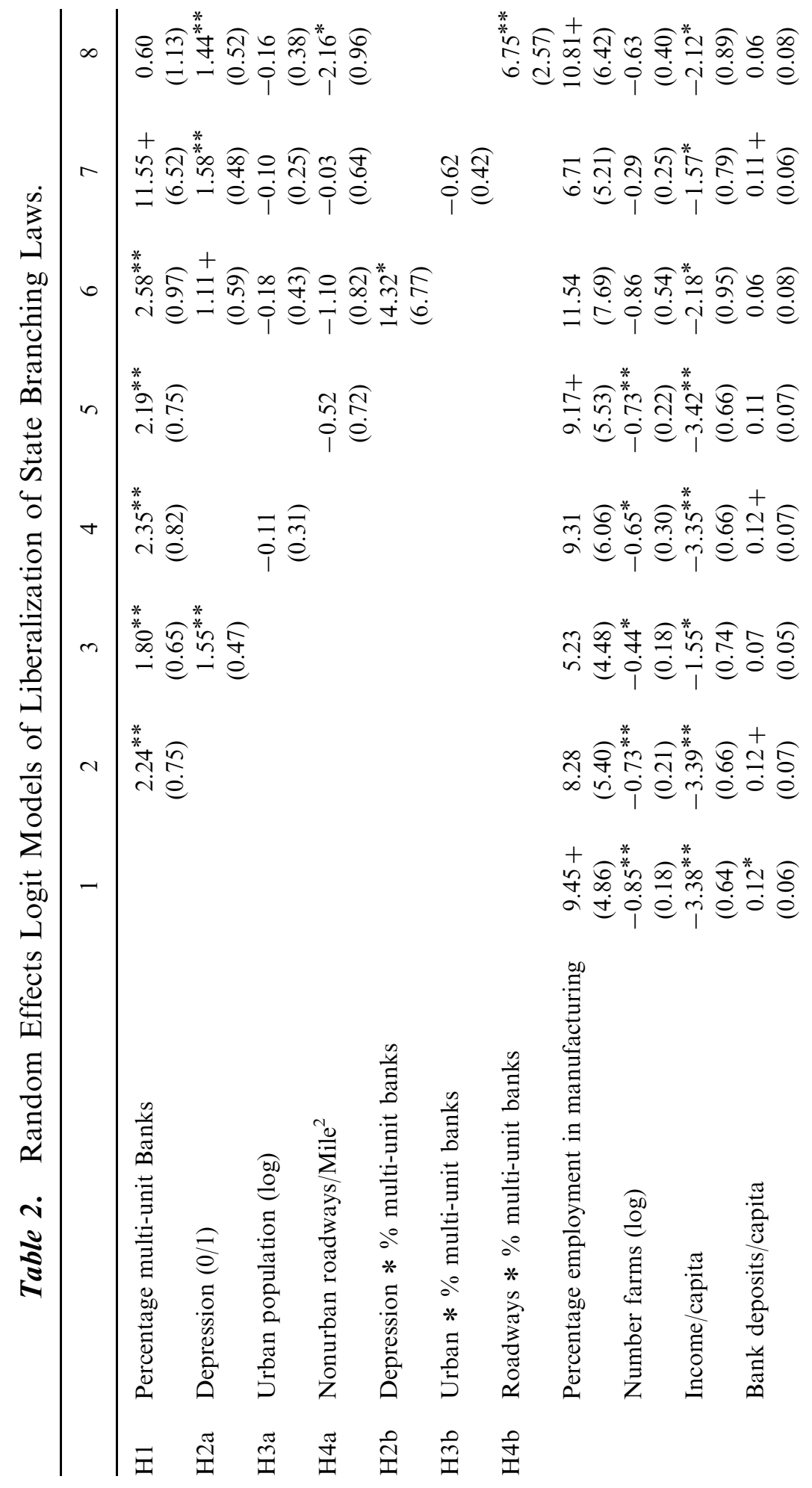




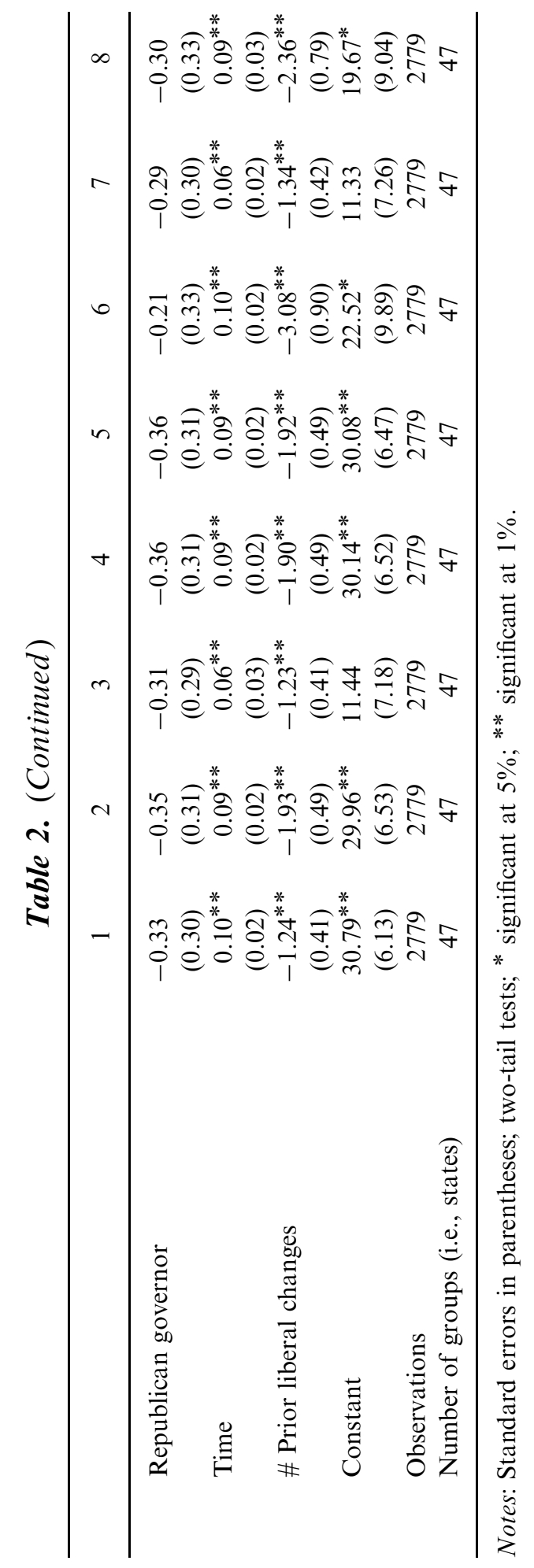


be expected from Fig. 1, the estimated coefficient of the Depression dummy is strongly significant with a positive sign, supporting Hypothesis $2 \mathrm{a}$.

The tests of the hypotheses regarding modernizing influences on the passage of liberal bank branching laws are not fully consistent with our expectations. As shown in Models 4 and 5, neither the main effect of urbanization or that of non-urban roadways was significant. Hence, Hypotheses $3 \mathrm{a}$ and $4 \mathrm{a}$ were not supported. Model 6 tests Hypothesis $2 \mathrm{~b}$. The estimated coefficient of the interaction term is positive and statistically significant, strongly supporting the hypothesis that the presence of multiunit banks accentuates the Depression effect. Model 7 tests Hypothesis $3 \mathrm{~b}$. The interaction between urbanization and the presence of multi-unit banks is not significant, and Hypothesis $3 \mathrm{~b}$ is not supported. But the interactive effect of non-urban roadway infrastructure and the presence of multi-unit banks as shown in model 8 was a significant determinant of whether a state passed a more liberal branching law. This finding, which supports Hypothesis $4 \mathrm{~b}$, suggests that perhaps it is transportation development and associated suburbanization processes in combination with existence of multi-unit banks that is the most important force relating to modernization that leads to legal changes in the banking context.

\section{DISCUSSION AND CONCLUSIONS}

This chapter analyzed the process of historical change that resulted in the US banking industry's shift in dominant institutional logics. The dominant logic at the turn of the twentieth century was that of community control and single-unit operations. The appropriate geographic domain of US banks was subsequently extensively contested, and significant variation developed among US states in the degree to which branching was permitted. Over the course of the twentieth century, the dominant institutional logic of the industry shifted to that of nationally oriented banking. We examined the processes under-girding this transition by an exploratory examination of historical meeting minutes of bankers associations and also statistically through event history analyses of when states passed more liberal bank branching laws. Our main thesis is that institutional transitions are often the combined result of endogenous processes on the one hand, whereby actors with opposing logics compete with each other to gain dominance, and exogenous changes on the other. This either creates opportunities for competing actors to reshape the balance of power or attenuate competition by inducing actors to change beliefs and identities. 
As expected, states in which a relatively greater number of the actors supported a given logic were more likely to codify that logic into law. Although the hypotheses regarding the main effects of exogenous changes (i.e., the Great Depression and modernization) receive only mixed support, such findings themselves are actually consistent with our contention that the influence of exogenous changes on institutional changes is at least partly contingent on how actors with different beliefs and identities react to such changes. Our further analysis shows that the effect of the Great Depression and the development of transportation highly depends on the relative presence of strategic groups of actors. This finding suggests that these external changes were not the punctuated and relatively unproblematic events as portrayed in prior work. With these findings, we highlight some implications of this study below.

\section{Competing Logics and Organizational Identity}

We witnessed through our historical study nearly a century of struggle and debate over two competing logics that were central to US society and that were extensively promoted by the organizations whose identities were defined by those logics. Consistent with prior research, the logics of banks, which were tied to their identities (Almandoz, 2010; Marquis \& Lounsbury, 2007), were longstanding. But unlike prior research, our analysis shows that these identities guided strategic action as bankers worked to convince legislatures and the public that their logic was the most appropriate vision for not only the banking sector but for society more generally. Identity and interest combine as strategic actors mobilize politically to shape laws and interpret historical events in agreement with the institutional logic embodied in their organization's identity. Thus, unlike research that shows how institutional change happens as novel logics take hold among professionals (Rao et al., 2003), or research that shows how differing organizational identities passively coexist in a field (Lounsbury, 2001), we witness the microdynamics of how organizations act strategically, guided by their identities and interests, striving to change broader conceptions of what is socially desirable and politically feasible, taking advantage of opportunities presented to them by historical events.

We further suggest that one reason for the lengthy period of stability during this contest of competing logics is that other features of external environments provided varying degrees of support for the opposing groups' identities. Our historical study suggests that modernizing environments had 
a priming effect on organizations by alerting them to the possible choices and opportunities that might become available to them, and thereby supporting the nationally oriented logic. Our statistical analyses confirm that expansion of the non-urban transportation infrastructure in combination with the presence of multi-unit banks influenced changes in bank laws. Although organizational identities are typically seen as quite durable, here we find that some single unit actors were apparently willing to shift their identities as the external environment changed. The historical meeting minutes suggested that there is significant variance on this process as some banks and bankers continually defend their position while others gradually shifted identities as the new economic reality took hold.

\section{Dominant Logic Transitions and Historical Periods}

We conceptualize the process of historical change as an interactive model, concluding that patterns of discontinuous change are not fully exogenous, but that they are expedited by an endogenous component. Legal changes, typically conceptualized as exogenous and often measured in terms of major federal legislative acts that clearly define historical periods (Davis et al., 1994; Scott et al., 2000), are among the most frequent markers of transitions in dominant logics and consequent transformations of firm behavior. Returning again to Fig. 1, we found a more complex pattern than would be suggested by the graph that shows multiple stable eras punctuated by periods of rapid change, suggesting that these were really culminations of periods of opposition over the appropriate organizing logic for the industry. Although the quantitative analysis may not fully reveal such processes, there is qualitative evidence. As noted, in contrast to widely accepted accounts that it was the disproportionate failure of unit banks that contributed to the economic crises and that branching laws were a solution, unit bankers maintained that the Depression era legislative changes resulted from the political work of multi-unit bankers. The unit bankers contention is supported by recent economic history that finds that multi-unit banks were just as susceptible to failure as were unit banks (Carlson \& Mitchener, 2005), suggesting that the changes were more a result of multi-unit bankers successfully framing the issue (Benford \& Snow, 2000) than of the economic reality at the time.

The historical meeting minutes suggest further that large exogenous shocks occurred frequently, particularly in the first half of the twentieth century. For example, in addition to 1929 , there were major economic crises in 1896, 1901, and 1907. Other major events that impacted the economy and 
are frequently seen as demarcating periods include two world wars and significant federal changes or debate that influenced branching legislation in 1927 (the McFadden Act), 1937 (the McAdoo Act for national branching which was extensively debated, but not passed), and 1955 (the Bank Holding Company Act). Interestingly, there is evidence that some of these shocks had localized effects on state branching laws, which were connected to the presence of strategic actors. The branch banking law enacted in California in 1909, for example, was widely agreed to be a response to the panic of 1907 (California State Bankers Association, 1909, pp. 78-130) combined with the institutional entrepreneurship of Bank of America founder A. P. Giannini (James \& James, 1954), and Georgia's decision to restrict its banking law in 1927 to have resulted from the failure of a branch bank system the year before and the passage of the McFadden Act (National Association of Supervisors of State Banks, 1937). Our point is that there is no shortage of major social, economic, and political shocks during historical eras. But, as the series of interaction effects we present shows, to understand which shock precipitates a change in the dominant logic one needs to consider as well endogenous factors and, in particular, strategic features of politically oriented actors. This suggests a somewhat counterintuitive conclusion that endogenous features must be present for discontinuous change to occur. Although it is typically assumed that the existence of discontinuous change is prima facie evidence of dramatic exogenous change, these results combined with our exploratory historical analyses suggest somewhat the opposite. Frequent shocks and transitions occur when strategic actors are able to capitalize on shocks. The effects of other, more gradual exogenous change processes are also shown to be better understood as interactions between exogenous and endogenous forces. Although others have found modernization to be a primary driver of changes in the structure of thrifts in California (Haveman \& Rao, 1997), looking across all US states, we find modernizing forces to have an effect only when the requisite strategic actors are relatively more powerful.

The view of organizations as logic-infused strategic actors working not only to sell deposit and loan accounts, but also to recast the field to be consistent with their worldview and identity, suggests that the effects of identity and logics-oriented movements might be more pervasive than previously thought. The control variables used in the study provide some suggestion that farmers, and manufacturers as well, might have been active participants in advocating the community and national logics, respectively. Recent research has shown similarly that the logic of banks is influenced by other organizations in the environment such as volunteer organizations, and other financial institutions (Almandoz, 2010). Although prior work has 
suggested that similar identity-related strategic action is operant in the sphere of cultural consumption (Carroll \& Swaminathan, 2000; Rao et al., 2003), as we have shown here, community versus national orientations in organizations can also be seen as a battleground for identity-related cultural and political contestation.

We further emphasize however that the contestation between the community logic and the national logic is not unique to the banking industry but widespread in many other industries and domains in the US society (e.g., Ingram \& Rao, 2004). Additionally, although our analyses may suggest otherwise, we recognize this struggle is still alive. Although by some measures such as state banking laws, the national logic clearly appears to have replaced the community logic, by others however, such as new bank foundings, the community logic appears to live on (Almandoz, 2010; Marquis \& Lounsbury, 2007; see also Marquis \& Battilana, 2009). Thus, the values, beliefs, and motives created by this logic are still present in US society and can potentially be reactivated when opportunities arise. For example, in addition to the recent increase in community bank foundings, there has been significant recent resistance against the invasion of gigantic corporations like Wal-Mart into local communities (Ingram, Yue, \& Rao, 2010). We believe that this recent revival of the community logic is quite consistent with our theory; as long as there are believers of the community logic, exogenous changes may provide opportunities for these actors to reassert the merits of the community logic. Many, for example, have commented that financial crisis of 2008 could well be one of those exogenous shocks similar to the Great Depression that could reconfigure the balance of logics, but this time in favor of the community logic. For their active role in the crisis, Wall Street banks and other "too-big-to-fail" financial institutions have been denigrated as icons of greed. In settings where bank customers and regulators receive those arguments favorably, one could expect a resurgence of the community logic (Almandoz, 2010). Against the backdrop of our study, this suggests that seemingly long dead logics may just remain dormant and look for opportunities to regain life in one way or another, and such opportunities are often created by large-scale exogenous changes which allow advocates to launch a forceful attack on the dominant logic.

\section{NOTES}

1. Bankers were tied to trade associations for many reasons, not only the aforementioned broader issues such as burglary and insurance, but also many areas 
of common ground such as expansion of bank holidays. There were also issues of maintaining the trust of peer institutions and of identity relating to their profession as bankers and connection with their states (Haveman \& Cohen, 1994). Trade association membership was broad and, because of the extensive access of these groups, the debate between groups of banks intent on pressing for the endorsement of their respective organizing logics played out within the associations. This suggests that the actors responsible for strategically framing the respective logics are important variables in understanding which would come to dominate.

2. New Jersey association minutes, for example, frequently recount members' letter writing efforts and time spent in Trenton and delivering briefs to legislature members. The amount of activity was staggering. Meeting minutes record that in New York alone, "[c]irculars, bulletins and letters have been sent on an average of three a month, or more than 40,000 mailings. Including letters, more than 45,000 pieces of mail have been issued from the office. We have had more than 3,600 outgoing telephone calls and 125 outgoing telegrams" (New York State Bankers Association, 1932, p. 16). It is clear, moreover, that the influence of these state and national banker associations derived from their frequent and direct access to the lawmaking apparatus and the fact that they represented a consolidated voice for state bankers. Although examples abound of direct contact between bankers representing trade associations and legislators, the indirect influence of these organizations is perhaps even more telling. For example, in almost every year studied, the governors of the given states addressed the annual bankers meetings and were involved in other convention events such as dinners, and national-level leaders such as sitting and former secretaries of Commerce and Treasury, Federal Reserve Board members, and other notable policy makers frequently attended various state bankers meetings.

3. Only recently have economic historians challenged this conventional wisdom and come to realize that branch banks were just as susceptible to failure in the depression as single unit banks (Carlson \& Mitchener, 2005).

4. A survey by the Comptroller of the Currency reported in Chapman and Westerfield (1942) contains information on branching regulations in 1896. We used this survey, cited by a number of sources as the first survey of branch banking in the United States, as my starting point in compiling histories of bank laws. Fischer (1968), referencing the Comptroller of the Currency and National Monetary Commission, details regulatory changes between 1896 and 1909. For this early period, we also examined the "Digest of State Banking Statutes" compiled by the National Monetary Commission. Bradford's (1940) The Legal Status of Branching in the United States contains information assembled from a periodic publication of the Federal Reserve for the years 1910, 1924, 1929, 1932, 1936, and 1939. We also examined the Federal Reserve publication "State Laws Relating to Branch Banking" (Federal Reserve Bulletin, March 1925; April 1930; July 1932; November 1936; October 1939; July 1951 contains the text of the state statutes). Fischer's (1968, pp. 62-63) state-by-state breakdown of intrastate banking and regulations between 1924 and 1967 documents the years of changes. The Federal Reserve's monograph-length Compilation of Federal and State Statutes Relating to Branch Banking, published in December 1956 and October 1967, contains the statutes at those times. For the period after 1967, we use the Conference of State Bank Supervisors' A Profile of State-Chartered Banking (various years), published bi-annually beginning in 1965. Berger, Kashyap, and Scalise 
(1995) have made a summary of laws since 1960, and Rhoades's (1981) "Banking Structure and Performance at the State Level During the 1970s" recounts the regulations in effect during the 1970s. For some of the earlier years for which we had to make assumptions about branching regulations, we relied on Fischer (1968), who maintains that regulation during this period was in many cases by custom rather than law. We followed his assessment of the type of branching enforced in a given state. For the few cases for which we did not have branch law information for a particular year, we assumed the legal history to be continuous (e.g., if we had information that Illinois was a unit banking state in 1911 and 1915, we assumed it to have been a unit banking state from 1912 to 1914).

5. Typically, branching regulations are categorized as unit, limited, and statewide; we used a four-category system to better capture the frequency of changes during the period.

6. Results are consistent when run without interpolated years.

7. To accomplish this, we used the percent change in total national highway mileage (data for which exists back to 1900) for each year to determine how much nonurban mileage increased each year. By 1900, the end of this data series, total national mileage is reduced to 100 . To obtain the 1896 to 1899 values, we linearly interpolated for each state under the assumption that in 1896 there were 0 miles.

\section{ACKNOWLEDGMENTS}

We thank Julie Battilana, Jerry Davis, Frank Dobbin, Mary Ann Glynn, Candy Jones, Michael Lounsbury, Mark Mizruchi, Jason OwenSmith, Richard Sylla, and seminar audience members at Harvard, Oxford, Michigan, Texas, Virginia and the 2006 Business History Conference for their comments on prior versions. We thank the Baker Library staff at Harvard Business School for help obtaining historical materials.

\section{REFERENCES}

Abrams, B. A., \& Settle, R. F. (1993). Pressure-group influence and institutional change: Branch-banking legislation during the great depression. Public Choice, 76, 687-705.

Albert, S., \& Whetten, D. A. (1985). Organization identity. In: L. L. Cummings \& B. M. Staw (Eds.), Research in organizational behavior (Vol. 7, pp. 263-295). Greenwich, CT: JAI Press.

Allison, P. (1995). Survival analysis using the SAS system. Cary, NC: SAS Institute.

Almandoz, J. (2010). The Invisible Hand and the Good of Communities: The Influence of Institutional Logics on Founding Teams of Local Banks: 212. Cambridge, MA: Unpublished doctoral dissertation, Harvard University.

American Bankers Association. (1902, 1912, 1933), Various Years. Proceedings of the Convention of the American Bankers' Association. New York: American Bankers Association, 1876-1919. 
American Institute of Banking (AIB) (1927). Various Years. Proceedings of Departmental Conferences held at the Convention, New York.

Barley, S. R., \& Tolbert, P. S. (1997). Institutionalization and structuration: Studying the links between action and institution. Organization Studies, 18(1), 93-117.

Benford, R. D., \& Snow, D. A. (2000). Framing processes and social movements: An overview and assessment. Annual Review of Sociology, 26, 611-639.

Berger, A., Kashyap, A., \& Scalise, J. (1995). The transformation of the U.S. Banking industry: What a long, strange trip it's been. In: W. Brainard \& G. L. Perry (Eds.), Brookings papers on economic activity (Vol. 2, pp. 55-218). Washington: Brookings Institution.

Bradford, F. (1940). The legal status of branch banking in the United States. New York: American.

Burstein, P., \& Linton, A. (2002). The impact of political parties, interest groups, and social movement organizations on public policy: Some recent evidence and theoretical concerns. Social Forces, 81(2), 380-408.

California State Bankers Association (1909). Proceedings of the Convention of the California Bankers' Association. Sacramento, CA: California Bankers Association.

Calomiris, C. (1993). Regulation, industrial structure, and instability in U.S. banking: A historical perspective. In: M. Klausner \& L. J. White (Eds.), Structural change in banking (pp. 19-115). New York: New York Business One-Irwin Publishing.

Carlson, M., \& Mitchener, K. J. (2005). Branch banking, bank competition, and financial stability. Cambridge, MA: National Bureau of Economic Research.

Carroll, G. R., \& Swaminathan, A. (2000). Why the microbrewery movement? Organizational dynamics of resource partitioning in the U.S. brewing industry. American Journal of Sociology, 106(3), 715-762.

Chandler, A. D., Jr. (1977). The visible hand: The managerial revolution in American business. Cambridge, MA: Harvard University Press.

Chapman, J. M., \& Westerfield, R. B. (1942). Branch banking: Its historical and theoretical position in America and abroad. New York: Harper.

Collis, C. W. (1926). The branch bank question. New York: MacMillan Company.

Comerica Bank (1999). Promises kept: The story of comerica, 1849-1999. Detroit: Comerica Bank.

Conference of State Bank Supervisors. Bi-annual, beginning in 1965. A profile of state-chartered banking. Washington, DC: Conference of State Bank Supervisors.

Cress, D. M., \& Snow, D. A. (2000). The outcomes of homeless mobilization: The influence of organization, disruption, political mediation, and framing. American Journal of Sociology, 105(4), 1063-1104.

Davis, G. F., Diekmann, K. A., \& Tinsley, C. H. (1994). The decline and fall of the conglomerate firm in the 1980s: The deinstitutionalization of an organizational form. American Sociological Review, 59(4), 547-570.

Davis, G. F., \& Thompson, T. A. (1994). A social movement perspective on corporate control. Administrative Science Quarterly, 39(1), 141-173.

Dobbin, F. (1994). Forging industrial policy: The United States, Britain, and France in the railway age. New York: Cambridge University Press.

Dodd, D. (1993). Historical statistics of the states of the United States. Westport, CT: Greenwood Press.

Federal Reserve Bulletin. Various issues: Washington, DC: US Government Printing Office.

Federal Reserve System-Board of Governors. (U.S.). (1956 \& 1967). Compilation of Federal, State, and territorial statutes relating to branch banking. Washington, DC. 
Fischer, G. C. (1968). American banking structure. New York: Columbia University Press.

Fligstein, N. (1990). The transformation of corporate control. Cambridge: Harvard University Press.

Friedland, R., \& Alford, R. (1991). Bringing society back in: Symbols, practices and institutional contradictions. In: W. W. Powell \& P. J. DiMaggio (Eds.), The new institutionalism in organizational analysis. Chicago: The University of Chicago Press.

Garrett, T., Wagner, G.A., Wheelock, D.C. (2003). A spatial probit analysis of state banking regulation: Federal Reserve Bank of St. Louis Working Paper 2003-044A.

Gioia, D. A., Schultz, M., \& Corley, K. G. (2000). Organizational identity, image, and adaptive instability. Academy of Management Review, 25(1), 63-81.

Greenwood, R., \& Hinings, C. R. (1996). Understanding radical organizational change: Bringing together the old and the new institutionalism. Academy of Management Review, 21(4), 1022-1054.

Greenwood, R., \& Suddaby, R. (2006). Institutional entrepreneurship in mature fields: The big five accounting firms. Academy of Management Journal, 49(1), 27-48.

Haveman, H. A., \& Cohen, L. E. (1994). The ecological dynamics of carrers: The impact of organizational founding, dissolution and merger on job mobility. American Journal of Sociology, 100(1), 104-152.

Haveman, H. A., \& Rao, H. (1997). Structuring a theory of moral sentiments: Institutional and organizational coevolution in the early thrift industry. American Journal of Sociology, 102(6), 1606-1651.

Huber, E., Ragin, C., \& Stephens, J. D. (1993). Social democracy, christian democracy, constitutional structure, and the welfare state. American Journal of Sociology, 99, 711-749.

Ingram, P., \& Rao, H. (2004). Store wars: The enactment and repeal of anti-chain-store legislation in America. American Journal of Sociology, 110, 446-487.

Ingram, P., Yue, L. Q., \& Rao, H. (2010). Trouble in store: Probes, protests, and store openings by Wal-Mart, 1998-2007. American Journal of Sociology, 116(1), 53-92.

James, M., \& James, B. (1954). Biography of a bank: The story of bank of America. New York: Harper and Brothers.

Kraatz, M., \& Block, E. S. (2008). Organizational implications of institutional pluralism. In: R. Greenwood, C. Oliver, R. Suddaby \& K. Sahlin-Andersson (Eds.), The sage handbook of organizational institutionalism, (pp. 243-275). London: Sage Publications Ltd.

Kroszner, R. S., \& Strahan, P. E. (1999). What drives deregulation? Economics and politics of the relaxation of bank branching restrictions. Quarterly Journal of Economics, 114, 1359-1398.

Kuhn, W. E. (1968). History of Nebraska banking: A centennial retrospective. Lincoln, NE: University of Nebraska Press.

Leblebici, H., \& Shah, N. (2004). The birth, transformation and regeneration of business incubators as new organisational forms: Understanding the interplay between organisational history and organisational theory. Business History, 46(3), 353-380.

Lee, E., Miller, A., Brainerd, C., \& Easterlin, R. (1957). Population redistribution and economic growth, United States, 1870-1950. Philadelphia: The American Philosophical Society.

Lok, J. (2010). Institutional logics as identity projects. Academy of Management Journal, 53(6), $1305-1335$

Lounsbury, M. (2001). Institutional sources of practice variation: Staffing college and university recycling programs. Administrative Science Quarterly, 46(1), 29-56.

Lounsbury, M. (2002). Institutional transformation and status mobility: The professionalization of the field of finance. Academy of Management Journal, 45, 255-266. 
Lounsbury, M. (2007). A tale of two cities: Competing logics and practice variation in the professionalizing of mutual funds. Academy of Management Journal, 50(2), 289-307.

Marglin, S. A. (2008). The dismal science: How thinking like an economist undermines community. Cambridge, MA: Harvard University Press.

Marquis, C., \& Battilana, J. (2009). Acting globally but thinking locally? The influence of local communities on organizations. Research in Organizational Behavior, 29, 283-302.

Marquis, C., \& Huang, Z. (2009). The contingent nature of public policy and the growth of U.S. commercial banking. Academy of Management Journal, 52(6), 1222-1246.

Marquis, C., \& Huang, Z. (2010). Acquisitions as exaptation: The legacy of founding institutions in the U.S. commercial banking industry. Academy of Management Journal, 53(6), 1441-1473.

Marquis, C., \& Lounsbury, M. (2007). Vive la resistance: Consolidation and community-level professional counter-mobilization in US banking. Academy of Management Journal, 50(4), 799-820.

Meyer, J. W., \& Rowan, B. (1977). Institutionalized organizations: Formal structure as Myth and ceremony. American Journal of Sociology, 83(2), 340-363.

Mizruchi, M. S., \& Stearns, L. B. (2001). Getting deals done: The use of social networks in bank decision-making. American Sociological Review, 66, 647-671.

Mizruchi, M. S., Stearns, L. B., \& Marquis, C. (2006). The conditional nature of embeddedness: A study of borrowing by large U.S. firms, 1973-1994. American Sociological Review, 71(2), 310-333.

National Association of Supervisors of State Banks Convention. (1934). Proceedings of the ... annual Convention of the National Association of Supervisors of State Banks.

National Association of Supervisors of State Bank (1937). Proceedings of the annual convention of the National Association of Supervisors of State Banks. Vol. 35 (Parts 1936-1939). S.I.: s.n.

New Jersey Bankers Association. (1915). Proceedings. Atlantic City: New Jersey Bankers' Association.

New York State Bankers Association. (1932). Various Years. Proceedings of the Annual Convention of the New York State Bankers Association. New York: Jaques \& Co.

Rao, H., Davis, G. F., \& Ward, A. (2000). Embeddedness, Social identity and mobility: Why firms leave the NASDAQ and join the New York stock exchange. Administrative Science Quarterly, 45, 268-292.

Rao, H., Monin, P., \& Durand, R. (2003). Institutional change in Toque Ville: Nouvelle cuisine as an identity movement in French gastronomy. American Journal of Sociology, 108(4), 795-843.

Rao, H., Monin, P., \& Durand, R. (2005). Border crossing: Bricolage and the erosion of categorical boundaries in French gastronomy. American Sociological Review, 70(6), 968-991.

Rhoades, S.A. (1981). Banking structure and performance at the state level during the 1970s: Board of Governors of the Federal Reserve Working Paper.

Roe, M. J. (1994). Strong managers, weak owners: The political roots of American corporate finance. Princeton: Princeton University Press.

Schneiberg, M., \& Bartley, T. (2001). Regulating American industries: Markets, politics, and the institutional determinants of fire insurance regulation. American Journal of Sociology, 107, 101-146.

Scott, S. G., \& Lane, V. R. (2000). A stakeholder approach to organizational identity. Academy of Management Review, 25(1), 43-62. 
Scott, W. R., Ruef, M., Mendel, P. J., \& Caronna, C. A. (2000). Institutional change and healthcare organizations: From professional dominance to managed care. Chicago: University of Chicago Press.

Soule, S. A., \& Olzak, S. (2004). When do movements matter? The politics of contingency and the equal rights amendment. American Sociological Review, 69, 473-497.

Stryker, R. (2000). Legitimacy processes as institutional politics: Implications for theory and research in the sociology of organizations. Research in the Sociology of Organizations (Vol. 17, pp. 179-223). Oxford: JAI Press.

Tarrow, S. (1998). Power in movement: Social movements and contentious politics (2nd ed). Cambridge, UK: Cambridge University Press.

Thornton, P. H., \& Ocasio, W. (1999). Institutional logics and the historical contingency of power in organizations: Executive succession in the higher education publishing industry, 1958-1990. American Journal of Sociology, 105(3), 801-843.

Thornton, P. H., \& Ocasio, W. (2008). Institutional logics. In: R. Greenwood, C. Oliver, R. Suddaby \& K. Sahlin-Andersson (Eds.), The sage handbook of organizational institutionalism (pp. 99-129). Thousand Oaks, CA: Sage Publications Ltd.

Thornton, P.H., Ocasio, W., \& Lounsbury, M. (Forthcoming). The institutional logics perspective: A new approach to culture, structure and process. Oxford: Oxford University Press.

Tocqueville, A.d. ([1835]2000). Democracy in America. New York: Bantam Books.

Tönnies, F. (1887). Gemeinschaft und Gesellschaft: Abhandlung des Communismus und des Socialismus als empirischer Culturformen. Leipzig: Fues.

Tushman, M. L., \& Rosenkopf, L. (1992). Organizational determinants of technological change: Toward a sociology of technological evolution. In: B. M. Staw \& L. L. Cummings (Eds.), Research in organizational behavior (Vol. 14, pp. 311-347). Greenwich, CT: JAI Press.

Useem, M. (1993). Executive defense: Shareholder power and corporate reorganization. Cambridge, MA: Harvard University Press.

Weber, M. (1978[1968]). Economy and society. Berkeley: University of California Press.

White, E. (1984). Voting for costly regulation: Evidence from banking referenda in Illinois, 1924. Southern Economic Journal, 1084-1098.

Yamaguchi, K. (1991). Event history analysis. Newbury Park, CA: Sage Publications.

Zajac, E. J., \& Westphal, J. D. (2004). The social construction of market value: Institutionalization and learning perspectives on stock market reactions. American Sociological Review, 69(3), 433-457. 


\section{APPENDIX: PROCESS OF EXAMINING THE STATE BANKING CONFERENCE PROCEEDINGS}

We examined the State Banking Conference Proceedings of 20 different states and 4 separate National and Regional Banking Association Proceedings/ Conference Minutes. These include: Alabama (1927-1969); Arizona (1903/ 1905-1930); California (1907-1940); Illinois (1917-1952); Kansas (1911-1931); Louisiana (1914-1915); Maryland (1925-1945); Massachusetts (1905-1978); Michigan (1899-1948); Missouri (1903-1951); New Jersey (1906-1939); New Mexico (1916-1920); New York (1898-1941); Nebraska (1903, 1915); North Dakota (1911, 1932-1933); Oregon (1931); Pennsylvania (1896-1919); Texas (1925-1943); Washington (1902-1967/1968); Wisconsin (1912-1924);: Proceedings of the Convention of the American Bankers Association (1876-1939); National Association of Supervisors of State Banks Convention (1902-1941); American Institute of Banking Proceedings of Departmental Conferences (1924-1931); Pacific Northwest Conference on Banking (1936-1960).

These materials represent a very unique collection of documents housed at the Baker Library at Harvard Business School. Thus, the choice of these particular meeting minutes was driven in some senses by convenience since this is the only extant collection of such materials. In the majority of cases, these meeting minutes were verbatim transcripts of what transpired at the annual meetings, as recorded by stenographers. Not only were the scheduled presentations recorded, but also question and answer sessions and other business meetings of the association officials. The minutes were typically bound in annual volumes of 300-400 typewritten pages. These volumes appear to be mainly used internally, as a record for the associations and affiliated bankers, although toward the end of the period, a few associations appear to have distributed them more widely.

We approached the documents from an inductive standpoint. Over a period of six months, we spent an average of $2-3 \mathrm{~h}$ a day reading these volumes and taking notes. The volumes typically had a table of contents or program from the meeting, which help me narrow our search for information and debate on the branch banking issue. In some cases, these volumes had indices which we used to further refine our search. After identifying the relevant sections in each volume, we read them and marked the relevant pages that we wanted to revisit. The library then photocopied these pages for me, and we picked them up the next day. At which point, we 
read the photocopied pages again in more detail, making notes, and highlighting in the text important quotes or passages. Our notes and highlighted materials were then typed. The final document that includes all states is a total of 87 single-spaced typewritten pages, including both the quotes and our notes. 